\title{
The Substance of Identity: Territoriality, Culture, Roots and the Politics of Belonging
}

\author{
Vivian Besem Ojong* \& Mpilo Pearl Sithole**
}

\begin{abstract}
Post-apartheid South Africa is at the interface of defining its social fibre, but at the same time, it is faced with the challenge of dealing with historical mishaps such as acute socio-economic inequality, and all forms of social engineering of notions of identity. This has led thinkers and researchers to probe into what it means to be a South African. In a recent book titled 'Do South Africans Exist", Chipkin (2007: 178) introduced a discourse, questioning the notion of South "Africaness" based on territory and geography. Other recent writings on race and identity continue to question the wisdom of framing identities in terms of culture and other primordial substances. Such substances have brought about a notion of identity that has led to human catastrophes framed in terms of ethnic identities and racial differences. While this paper capitalizes on such criticism, it interrogates academic discourse for not 'coming out' with durable explanations of what identities are about and especially what constitutes them. This paper proposes a conceptual analysis and framing of the substance of identities that balances emic and etic explanations. In this formulation an exploration of a range of elements affecting conceptualization of identities is done, including notions of territoriality culture and roots.
\end{abstract}

* Vivian Besem Ojong,Department of Anthropology, University of KwaZulu-Natal, Durban. Email: ojong@ukzn.ac.za.

** Mpilo Pearl Sithole, Research Associate, Department of Anthropology, University of KwaZulu-Natal. Email: psithole@hsrc.ac.za. 


\section{Résumé}

Après l'apartheid, l'Afrique du Sud est dans une interface à définir son caractère social, et en même temps fait face à un défi, celui de l'inégalité socio-économique et toutes les formes de créations sociales des notions d'identités. Cela a poussé les chercheurs et les penseurs à revoir ce qu'être sud Africain veut dire. Dans un livre récent intitulé «Existe-t-il des Sud Africains ? ", Chipkin (2007: 178) a introduit une discussion en questionnant la notion de l'«Africanité du Sud » basée sur la territorialité et la géographie. D’autres écrits récents sur les questions de race et de l'identité continuent à questionner l'identité véritable en termes de culture et d'autres aspects primordiaux. Ceci fait naître une notion de l'identité qui a conduit aux catastrophes humains tels que les questions de l'identité ethnique et la différences raciales. Même si cette communication se focalise sur ces critiques, elle s'interroge aussi sur les discours académiques qui n'ont pas pu produire une explication durable sur ce qu'est l'identité et ces différentes composantes.

Cet article propose une analyse conceptuelle et des explications de la question de l'identité qui confrontent emic et etic. Dans cette formulation, il sera aussi question d'explorer certains éléments qui affectent la conceptualisation de l'identité, la notion de territorialité, culture et les origines.

\section{Introduction}

After the fall of apartheid, migration to South Africa has been on the increase and there is no natural conclusion in sight, conclusion being argued as undesirable in most quarters. This increase is continuous, since South Africa is perceived as rich compared to the rest of Africa and also is perceived as relatively safe since the fall of apartheid. Therefore, all categories of immigration have increased, including work permits, students who settle permanently, asylum seekers and undocumented migrants. Some of these immigrants do not wish to go back to their countries of origin (Ojong, 2005). At the same time, amongst those who have always lived in this border, South Africanness is not easy to define. Selfascription with South Africanness is often rudimentary, depending on context and advantage. This paper, therefore, examines South Africanness in the context of no rigid authenticity of this identity. The key questions are: what are the implications of increased and sometimes permanent migration for South African identity? Is the South African identity in the making or are there different 'shades' of South Africanness? While the point of focus here is South Africa, what we examine here is a phenomenon that has bearing on other countries as well. 
South Africa is a country laden with negotiation and renegotiation of its demography. A country in the process of re-drawing its social map with all aspects of its social fibre placed on the drawing board. Fifteen years after the first democratic elections, the social contours which constitute the beautiful 'rainbow' nation are difficult to define. Considering some of the debates as well as government supported programmes such as the African renaissance programme, it appears as though some inhabitants believe that they are more South African than others. The debates have been both academic and popular. On the one hand, there are those who cannot separate spatialisation and socialization as a basis for identity. For them, citizenship and nationality converge into an identity premised on territoriality. In this school of thought, spatialisation and socialization are believed to be tied together (Massey, 1994). The two are tied together, by an 'invisible umbilical cord'. Malkki (2002) calls this boundedness 'metaphysics of sedentarism', which she believes, territorialises our identities whether cultural or national.

The opportunity to look at identity from a stance of migration and relocation provides space to reflect on why citizens 'grade' themselves according to their history and ancestral roots. In South Africa, there is cry for belonging from members of historical settler groups, a discontent with not being regarded as fully African. At the same time, it is not uncommon for such citizens to embark on long trips to Europe or Asia tracing their 'roots' to Scotland or India. On the other hand 'indigenous culture' is often verbalized as something that has been permanently African as opposed to 'imported'; hence those who associate themselves with it are seen as 'more local' than others. This does not happen only when the subject of identity is directly invoked; it is also affirmed in the association of scientific heritage with 'the West' and association of extraobjective (cosmological) interaction, especially in healing, with Africa. The various diasporic 'brotherhoods' within the continent also affirm groups within space. The whole notion of diaspora presents tangible ambivalence to the notion of elastic identities.

Chipkin (2007) examines in detail what should constitute a national identity. He examines the politics of nationalism from the 'politics-ofbelonging' point of view. However, in the process, he reifies nationalism, subduing and trivializing all other forms of identity. Given the long standing lamentation against smaller identities as being the basis for negative competition and detrimental fissions, it is no surprise that Chipkin does not waste his time pondering on these identities. Unfortunately, this shuns not just these forms of identities but an opportunity to examine 
how the human species categorizes identity, what motivates it to crystallize identities temporarily or permanently. In Chipkin's analysis, we see the analyst starting from a 'political' commitment to one form of identity rather than being at liberty to follow through what informs human tendencies to consolidate an identity, how and when.

Our point of departure is the realization that identity for the migrants or the relocated cannot be solely constructed in bounded places and located in it but should embrace elastic connotations and interpretations. Space has always been of keen interest to Anthropologists because their population of study has historically been located in fixed places (Lefebvre, 1991; Moore, 1986), and this has been the basis for assuming some essentialist characteristics. Dougan (2004:33) has argued that essentialist conceptualizations serve the key function of providing permanent, clear and thick boundaries. In a sense, it is not clear what comes first - essentialism or territory. It is the tendency to essentialise, which we argue, is at the crossroads of the emic and the etic conceptions of identity. Identities, therefore, become fundamentally instrumentalist, but retain an emic justification of being authentic through being associated with essentialising symbols that are cultural, territorial or embedded in the notion of roots.

All human beings have an embodiment of norms and values which they carry along when they move to other places; be it translocally or transnationally. Owing to the influence of globalisation, these embodiments are easily shared by all who occupy a geographic space. Gupta and Ferguson (2001) have argued that these embodiments are lived in spaces which have been culturised. South Africa in the past one hundred and fifty years has experienced significant immigration from the rest of the world which has shaped and continues to shape its national identity. It is perhaps for this reason that to some inhabitants who form the demography of the country, place cannot be a clear support of their identity. Yet for others, even those who have migrated internally (i.e. within South Africa), the notion of 'roots' makes what they regard as a true home. From an observer point of view it is clear that through interacting and living with people from different origins, new identities are created, socialization process is renegotiated and meanings that people attach to places are re-visited. 


\section{Theoretical Confusion on the Notion of Identity: South Africa as a Site}

Controversy rests on the question of whether common place descriptors as a basis for definitions of identity are suitable for a proper understanding of identity in a transnational and migratory context. In the context of multiple cultural encounters, is it justified to assume a clear social and physical reality as a base for identity? Malkki (2001:56) writes that "people are often thought of, and think of themselves, as being rooted in a place and as deriving their identity from that rootedness. According to Gellner (1981:4) this has to do with the manner in which researchers have often conceptualized the spatial arrangements of peoples.

Before Africa's encounter with colonialism, composition of societies was fluid in nature and membership was not fixed but was readily permeable by non-members. People could move from one geographic location to another and join other groups and easily acquired the identity of that location. However, contemporary notions of group identity in Africa have created thick boundaries with alienating properties and when a group is not considered as having those properties, they are labelled outsiders. Appiah (1992:175) notes that group identity seems to work only, or at least, to work best when it is seen by its members as natural, as real. Writing about group identity, Boonzaier and Sharp (1989:2) agree that "one cannot assume that any representation of the society is a straight forward description of its real nature, because each representation is a political statement which includes assumptions and intentions of the people who make it". However, since the 1980s many South African academics have tended to see identities mainly in instrumentalist terms where people use identity as a means to materialist ends. Rogers and Cooper (2000) have made a distinction between self-identification and the identification and categorisation of oneself by others. According to these authors, it is dialectic interplay with a point of convergence. They, however, highlighted a 'third force' of identification, which is an authoritative voice usually orchestrated by the state to categorise people. Such is demonstrated through the use of passports, but the authors question the oversight exercised with the use of such mode of identification. What Rogers and Coopers overlooked is the fact that every mode of expression is a statement (whether through a photograph or a passport), a declaration of who we are.

It is important to realise the fact that individuals' construction of identity takes place alongside others' labeling, political processes and ideology. This creates a sense of 'us and them' which creates the politics 
of belonging and not belonging to which certain thinkers (e.g. Chipkin, 2007 discussed above) focus all their attention. This is obviously a sensitive matter, since it is not fair to exclude people from the South African identity while they strongly believe that they belong. However, what are the parameters of belonging or at least criteria to join. Is legitimate joining (presumably compliant with some criteria) enough as a statement of 'authentic South African identity'. Once demarcated boundaries are created, which converts insiders into outsiders, it leads to deconstruction upon deconstruction of identities. Instead of having identities being transformed and reproduced as Hall (1996) has stated earlier, deconstruction sets the pace for identification. It is not being suggested here that an open 'melting pot' be created whereby all the different 'cultures'/identities that find themselves in the geographic space called South Africa should simply belong. That would mean abolishing boundaries without giving the rationale or conceptually conceding to territoriality of identities without solving the problem of temporality (of migration whether short or permanent) and the relevance of sociality or socialization. However, the problem of what constitutes identities has not been solved by academic discourse. In South Africa, it is particularly difficult to arrive at neutral critical discourse on identities because of the past which makes academics champion some form of identity before scrutinizing human tendencies in self-categorization.

A legacy which the apartheid government has left behind which continues to haunt South Africans consciously or unconsciously, is ethnic consciousness. The apartheid government called social groups 'ethnos', which were assumed to be closed systems into which individuals were born and only death could separate them from their 'ethnos'. Although the ideology at the time was for political gain, it has created a strong sense of ethnic identity, which when placed on a scale, supersedes the South African identity. The different diasporic groups which form part of the South African identity today, the 'more indigenous' groups, as well as emergent ones from the rest of the African continent, all retain a potential to essentialise their history of origin (origin being relative to current status and its issues).

Since identification often to a great extent determines who accesses resources and who does not, ethnic identity is being elevated above the national identity. People are quick to assert that they are: Zulu, Sotho, Xhoza, etc. Others are comfortable being called White, while others are called Indians. The other emergent groups from the rest of Africa who by choice have naturalised as South Africans do not belong. They are called 
'amakwere-kwere'. ${ }^{2}$ This pattern of identification enshrines demarcated boundaries and is fraught with discrimination, probably indicating current trends in material competition. By identifying firstly through ones' ethnic lineage, some people are seen as more South African than others. Consciously or unconsciously, such boundaries play a pivotal role in accessing resources. Some of these groups are seen as 'natural' (Appiah, 1991), while others are seen as 'transplanted' (Mudimbe-Boyi, 2002; Malkki, 2002). Some are 'diasporic' (Hall, 1996), while others are 'indigenous' (Sylvain, 2002). Some are labelled 'transnationals' while the rest are either 'immigrants' or 'migrants'.

\section{South African Identity as Description and Labelling}

'We know of no people without names, no languages or cultures in which some manner of distinctions between self and other, we and they, are not made....self knowledge is always a construction, no matter how much, it feels like a discovery, is never altogether separable from claims to be known in specific ways by others' (Calhoun, 1994:10).

In order to understand how people in South Africa identify themselves and how they are perceived by others, we did a small exercise with Anthropology first year (new students) and honours students (mature students) at the University of KwaZulu-Natal among whom were; 'whites' 'blacks' and 'Indians'. A double question was posed to them: Who is a South African and who is African? It emerged that the different racial groups used different grounds for identification. The Black students where confident that they were South Africans because of their skin colour and their language (according to this group, Africa naturally belongs to Black people). The White students had a loose construction of identity (not using territory) by saying that anyone could be a South African, but were confident they were South Africans. The Black students did not, however, consider the whites to be African because they did not belong to the Black culture and did not speak their language and had a kind of culture which was not of South Africa. Their belief was that the Whites are poised to be South Africans by historical circumstances. Some were quite blatant with arguments of opportunistic materialism suggesting that white South Africanness is predicated on a desire to have access to resources and benefit from the political positioning of South Africa vis-à-vis the world and the rest of the African continent. The Indians, on the other hand, had a different construction of identity. Their identity was constructed in terms of India as their 'motherland'. They all easily identified themselves as Indians. One may ponder as to 
why they thought of territorial land in the construction of their identity. The reason may rest in the fact that they had always been marginal in White dominated South Africa and were marginal during the Black dominated era and were, therefore, keeping their connections.

This highlights the fact that there are different levels of identification; self perception, external attribution, which are all multiple, fluid, shifting and situational. Our self-perception of where we belong in society does not necessarily coincide with how others identify or classify us. It would seem from the above that there is an urgency for a strong sense of nationhood to be created in South Africa the substance which Chipkin (2007), taking from others, discusses as 'fraternity'. Without a strong sense of South African national identity, we are poised to encounter generations upon generations of people being labeled foreigners.

Since identity is a freely chosen game as Doughlas (1992) has argued, perhaps individuals should be given the opportunity both theoretically and operationally to decide where to belong, by moving away from classical interpretations. To some extent individuals are already doing this, since sometimes they speak of formal or official identities on the one hand, and informal and real identities on the other hand. Some have lived in certain territories for a major part of their lives, but regard other places as the basis for their identities. Others care less about 'original places' and have carved identities from their current circumstances. The assumption that identities have a static territorial dimension misrepresents and misinterprets the South African identity. Classical theories of identity do not sufficiently grasp people's identity in a country with a high immigration like South Africa. According to Appadurai (1991:191), increased mobility has led to dispersed identities which are being reproduced. As migrants change geographical places, they enter distinct social spaces in which group memberships are renegotiated, so are the meaning of places as well as interpersonal ties. Hall (1996) theorizing the transformation of the notion of identity in relation to migration, considers it as a process of perpetual change.

Hall (1998:222) does not regard identity as an accomplished fact but as a production which is never complete, always in process, and always constituted within, not outside representation. Such identities are constantly producing and reproducing themselves anew, through transformation and difference. This would, however, suggest that identities are not static or predefined, but infinitely malleable (Woodward, 1997:313). 


\section{Conclusion}

This paper has pondered upon the meaning of identities from multiple angles which are of necessity a nuanced framework for defining identities. It is argued in this paper that in a final analysis, identities must not be approached from pre-conceived choices about which identities are better, even though such a 'political' standpoint might be the ultimate interventionist aim. Analysis of identities must be localized (i.e. they must relate to subjectivities and/or polities), taking into account the historical dimensions applicable to those involved. It should also be mindful of self-ascriptions of identity and labeling between people. Identities are therefore a matter of both the emic and the etic; they are influenced by a balance between self-assessment of identity markers as well as objective factors of social relations giving rise to renegotiation. Identities are therefore a process of 'essentialising-on-the-go' - objectively they are not permanent and rigid, but subjectively they are constituted by definite markers and existential substance, albeit experiential. Thus, we argue for space for both self-identification and explicit criteria for identity in officialdom - the latter being space for continued renegotiation.

\section{Notes}

1. A derogatory term used in identifying black foreigners in South Africa

\section{References}

Appadurai, A.,1991, "Global ethnoscapes: roles and queries for a transnational anthropology." in Fox, R. G. (ed). Recapturing Anthropology: working in the present Santa Fe. School of American Research Press.

Appiah, K.A., 1992, In My Father's House: Africa in the Philosophy of Culture. New York: Oxford University Press.

Boonzaier, E. and Sharp J., 1989, South African Keywords: The uses and abuses of political concepts. Cape Town: David Phillip.

Calhoun, C., 1994, Social Theory and the Politics of Identity, Oxford: Blackwell

Castels, M. 2000. The power of Identity, Oxford: Blackwell.

Chipkin, I., 2007, Do South Africans Exist?: Nationalism, Democracy and the Identity of the People Johannesburg Wits University Press.

Douglass, K., 1992, Popular culture and constructing postmodern identities in Lasch, S. and Friedman, J. (eds), Modernity and Identity, Oxford: Basil Blackwell.

Gellner, E., 1981, Muslim Society. Cambridge: Cambridge University Press.

Gupta, A. and Ferguson, J., 2001, Culture, Power, Place: explorations in critical anthropology, London: Duke University Press.

Hall, S., 1996, "Cultural identity and Diaspora", in Hall, S. (ed), Questions of Identity, Hamburg.

Hall, S., 1998, 'Cultural identity and Diaspora' in Rutherford, J., (ed), Identity, Community, Culture, Difference, London: Lawrence and Wishart. 
Lefebure, H., 1991, The production of space, Oxford: Blackwell Publishers. Malkki, L., 2002, National Geographic: The Rooting of Peoples and Territorializing of National Identity among Scholars and Refugees in Gupta, A. and Ferguson, J. (ed), Culture, Power, Place. Explorations in Critical Anthropology, London: Duke University Press.

Massey, D., 1994, Space, place and gender, Minneapolis: University of Minnesota Press.

Moore, H., 1986, Space, Text and Gender: An Anthropological study of the Marakwet of Kenya, Cambridge: Cambridge University Press.

Mudimbe-Boyi, E., 2002, Beyond Dichotomies. Histories, Identities, Cultures, and the Challenge of Globalisation, New York: State University.

Rogers, B., and Cooper, F., 2000, 'Beyond Identity', Theory and Society, Codesria Bulletin Vol. 29 (1): 1-47.

Sylvain, R., 2002, "Land, Water, and Truth", San Identity and Global Indigenism. American Anthropologist 104 (4): 1074-1085. American Anthropological Association.

Todorov, T., 1985, The Conquest of America: the question of the other, New York: Harper and Row.

Woodward, K., 1997, 'Concepts of Identity and Difference', Woodward, K. (ed). London: Sage Publications. 